scale, other small-scale tests in use are not sufficiently critical at this level.

The application of the sedimentation test to hybrids in advanced generations has been successful and the use of the test in the early generations of wheat crosses is under investigation. It may be possible to select for flour quality at the same time as for other agronomic characters.

$$
\text { L. G. COPP }
$$

Crop Research Division,

Department of Scientific and Industrial Research, Private Bag,

Christchurch, New Zealand. Nov. 22.

1 Zeleny, L., Cereal Chem., 24, 465 (1947).

\section{Abnormal Hæmoglobins in the Kasai Province of the Belgian Congo}

Hamoglobin $\mathrm{C}$ was first detected among American Negroes, and figures for its incidence range between 1.4.1 and 3 per cent ${ }^{2}$. As the anomaly seemed virtually absent in the white race, it was reasonable to suppose that the gene responsible for it had been imported from Africa in the times of slave trade. This was soon confirmed by a survey of Edington and Lehmann ${ }^{3}$, who found hæmoglobin $\mathrm{C}$ to be present in 12 per cent of 200 hospital out-patients in Accra (Gold Coast). Recently, individuals with this hrmoglobin have been reported from French North Africa ${ }^{4}$. It is also known to exist in Liberia and in French West Africa (Neel, J. V., personal communication).

In East Africa, surveys for abnormal hæmoglobins among natives from Uganda ${ }^{5}$, Southern Sudan and Tanganyika $^{6}$ did not provide any specimens of hæmoglobin C. In South Africa, hæmoglobin C was found in 2 out of 219 blood specimens of Cape 'coloured' individuals'. However, as Lehmann points out, these sporadic cases may be the result of the introduction of slaves from West Africa.

As no results for hæmoglobin C are available for Central Africa, we undertook an investigation at Luluabourg, a town of 40,000 inhabitants, situated in the Kasai Province to the south of the Congo Basin. Blood specimens for paper electrophoresis of hæmoglobin were obtained from 500 unrelated and unselected natives. Most of them were young adults belonging to the important Baluba tribe. 'The apparatus and the technique used were those already described by one of us $^{8}$. In addition to electrophoresis, all specimens were examined for sickling in 2 per cent sodium metabisulphite.

Of the 500 samples tested, $148(29 \cdot 6$ per cent) showed sickling. In all these instances the electrophoretic pattern was that of the heterozygous sickling trait. All other hæmoglobin samples showed a single component corresponding to normal adult hæmoglobin. The pattern of homozygous sickle-cell anæmia was not encountered in our sample. Although sickle-cell anæmia is a very common disease at Luluabourg (75 new cases were seen during the past ten months) we were never able to diagnose the disease in adults beyond the second decade.

Apart from this investigation, 35 further specimens were selected from patients suffering from different symptoms suggestive of sickle-cell disease. The hæmoglobin of one of these patients showed the electrophoretic properties of a hæmoglobin S-C mix- ture, and was thus diagnostic for sickle-cell hæmoglobin $\mathrm{C}$ disease. This patient was a male adult with slight anæmia, numerous target cells and a high percentage of red cells sickling in vivo. His chief complaint arose from a mutilating necrosis of the femoral head. A complete cese report of this patient has been published elsewhere?

The anthropological significance of this sporadic case has probably no more value than those found in the Cape 'coloured' population. The patient was originally from the enclave of Cabinda situated a few miles to the north of the Congo estuary. As there has been for generations a busy trade between the natives of Cabinda and those of the Guinea coast, the occasional presence of hæmoglobin $C$ is not surprising. This study in association with other surveys provides further evidence that the diffusion area for the gene of hæmoglobin $\mathrm{C}$ does not extend south of the equator.

This investigation was supported in part by State of Washington Initiative 171 funds for research in biology and medicine.
J. VANDEPITTE

Medical Laboratory,

Luluabourg,

Belgian Congo.
Arno G. Motulsky

University of Washington School of Medicine,

Department of Medicine, Seattle, Washington.
1 Neel, J. V., Amer. J. Hum. Genetics, 6, 208 (1954).

2 Schneider, R. G., J. Lab. Clin. Med., 44, 133 (1954).

${ }^{3}$ Edington, G. M., and Lehmann, H., Trans. Roy. Soc. Trop. Med. Hyg., 48, 332 (1.954).

${ }^{4}$ Portier, A., Cabannes, R., Massonnat, J., and Duval, J., Algerie

${ }_{5}$ Jacob, G. F., Brit. Med. J., i, 521 (1955)

${ }^{6}$ Roberts, D. F., and Lehmann, H., Brit. Med. J., i, 519 (1955).

7 Brain, P., and Lehmann, H., Nature, 175, 262 (1955).

${ }^{8}$ Motulsky, A. G., Paul, M. H., and Durrum, E. I., Blood, 9, 897 (1954).

- Vandepitte, J. M., and Colaert, J., Ann. Soc. Betge Méd. Trop., $35,457(1955)$.

\section{Orotic Acid as a Survival Factor in Rats Deficient in the Animal Protein Factors of Casein}

VIVIANI et $a l .^{1}$ have recently shown that orotic acid may be one of the growth factors for rats deficient in the animal protein factors of casein, but not for normal rats. These and previous ${ }^{2,3}$ observations suggest a possible relationship between orotic acid and animal protein factors of casein. Therefore, in the present work, our investigations have been extended to the significance of prophylactic feeding of orotic acid upon the most dramatic aspect of the deficiency of animal protein factors of casein, namely, the high mortality of the newly born of the first generation and the total mortality of the second generation.

To this end, we have divided from weaning (21 days of age) thirty female rats of the Sprague-Dawley strain into three groups and placed them on the three experimental rations described in Table 1.

In these three groups of female rats and in the female rats of the subsequent filial generations, the survival of young from birth to weaning has been recorded. The results are reported in Table 2.

From the above results it appears evident that orotic acid may be a new factor for the survival of newly born rats deficient in the animal protein factors of casein.

Since orotic acid does not appear to be essential to survival, we think that orotic acid may be: 